\title{
ANALISIS PENGARUH MANAJEMEN MODAL KERJA TERHADAP PROFITABILITAS PERUSAHAAN MANUFAKTUR SEKTOR INDUSTRI DASAR DAN KIMIA GO PUBLIC PADA BURSA EFEK INDONESIA (BEI) PERIODE TAHUN 2011 - 2014
}

\author{
Citra Indradewi*, Endang Tri Widyarti ${ }^{1}$ \\ citraindradewi@gmail.com \\ Jurusan Manajemen Fakultas Ekonomika dan Bisnis Universitas Diponegoro \\ Jl. Prof. Soedharto SH Tembalang, Semarang 50239, Phone: +622476486851
}

\begin{abstract}
This research aims to analyze the effect of working capital management on profitability of basic industry and chemicals that listed in Indonesia Stock Exchange (IDX) within 20112014. Indicator of working capital management used in this research are cash conversion cycle $(C C C)$, receivable conversion period $(R C P)$, inventory conversion period (ICP), payable deferral period (PDP), and current ratio $(C R)$. On the other hand, indicator of profitability used in this research is net profit margin (NPM).

The sample data used in this research took from financial statement that have been audited and published in IDX. According to sampling technique used in this research, which is purposive sampling, there're 25 companies that fit to certain criteria. Method of data analysis used in this research is Multiple Regression Analysis, which previously performed classical assumption test. Hypothesis test is using F-statistic test, $t$-statistic test, and determination of coefficients with significance level of $5 \%$.

The result of this research indicates independent variables simultaneously (F-statistic test) effect on profitability (NPM) with significance level 0,000. On the other hand, partially (t-statistic test) indicates CCC has negative and significant effect on profitability, $P D P$ and $C R$ have positive and significant effect on profitability. Meanwhile, RCP and ICP has positive and not significant effect on profitability. Adjusted $R^{2}$ 's score is 0,454 which means that the ability of independent variables can explain profitability with $45,4 \%$, while the rest is explain by other factors.
\end{abstract}

Keywords: working capital management, cash conversion cycle (CCC), receivable conversion period $(R C P)$, inventory conversion period (ICP), payable deferral period $(P D P)$, current ratio(CR), profitability, net profit margin (NPM).

\section{PENDAHULUAN}

Dalam segi pertumbuhan ekonomi, perekonomian Indonesia telah berhasil masuk dalam kategori tiga besar di Asia atas keberhasilannya. Salah satu komponen penting dalam pertumbuhan ekonomi nasional adalah sektor industri manufaktur. Berdasarkan data yang disampaikan Kementerian Perindustrian Republik Indonesia, pada tahun 2013 sektor industri manufaktur telah mencapai pertumbuhan hingga $6,4 \%$ dan memberikan kontribusi sebesar 20,8\% atau sekitar Rp 1.714 triliun terhadap Produk Domestik Bruto (PDB) nasional (Anindityo dalam Media Manufaktur Industri, 2013). Selain itu, Badan Koordinasi Penanaman Modal (BKPM) mengatakan realisasi penanaman modal dalam negeri (PMDN) untuk sektor industri manufaktur mengalami peningkatan sejak 2010 hingga 2014. Hal ini dapat ditinjau melalui realisasi investasi pada tahun 2013 mencapai Rp 398,6 triliun, sedangkan pada tahun 2014 meningkat menjadi Rp 463,1 
triliun atau sebesar $16,2 \%$ dari sebelumnya (Kompas, 2015). Salah satu sektor yang berperan aktif dan menonjol adalah sektor industri dasar dan kimia. Sektor ini mengalami perkembangan yang cukup pesat dan menggunakan modal yang cukup besar. Perusahaan manufaktur sektor industri dasar dan kimia merupakan sektor yang memiliki persaingan ketat. Hal ini diperkuat saat kenaikan IHSG sebesar 3,23\%, sektor yang mengalami peningkatan terbesar adalah sektor industri dasar dan kimia sebesar 6,83\%(Niko dalam Britama.com, 2014).

Setiap perusahaan, selalu memiliki salah satu tujuan yang sama yaitu meningkatkan profitabilitas setiap periode. Dalam mencapai tujuan tersebut perusahaan melakukan berbagai aktivitas operasional yang berguna dalam menghasilkan keuntungan. Aktivitas operasional yang dilakukan oleh perusahaan biasanya memerlukan biaya yang cukup banyak, baik untuk pelaksanaan kegiatan operasional maupun digunakan sebagai investasi jangka panjang. Biaya yang dibutuhkan perusahaan dapat bersumber dari modal kerja, penjualan, aset lain yang dimiliki perusahaan, dan utang. Dengan demikian, maka dapat diketahui salah satu faktor yang berperan dalam pembiayaan aktivitas operasional dan turut mempengaruhi tingkat profitabilitas adalah modal kerja.

Untuk mengetahui bagaimana pengaruh modal kerja terhadap tingkat profitabilitas, perusahaan memerlukan manajemen modal kerja yang baik. Metode pengukuran manajemen modal kerja yang terkenal yaitu siklus konversi kas atau cash conversion cycle (CCC) yang terdiri atas komponen modal kerja dan dihitung berdasarkan penjumlahan periode konversi piutang usaha atau receivable conversion period (RCP) dan periode konversi persediaan atau inventory conversion period (ICP) kemudian dikurangi periode penangguhan utang usaha atau payable deferral period (PDP). Pengukuran modal kerja juga turut ditinjau melalui current ratio (CR) untuk mengetahui seberapa mampu aset lancar perusahaan membiayai utang lancarnya.

Dalam penelitian ini, pengukuran profotabilitas dilakukan melalui salah satu rasio profitabilitas yaitu net profit margin (NPM), sebab penggunaan rasio NPM diharapkan dapat meninjau apakah perusahaan tersebut memiliki kinerja yang bagus dan telah melakukan kegiatan operasional secara efektif dan efisien dengan menekan biaya-biaya operasional yang tidak perlu sehingga perusahaan mampu memaksimalkan laba bersih yang didapat. Melalui rasio NPM manajer operasi dapat menetapkan strategi harga yang tepat guna menekan beban operasional yang dikeluarkan sehingga berdampak terhadap peningkatan laba bersih.

Berdasarkan fenomena gap yang terjadi NPM mengalami peningkatan di setiap tahunnya, diikuti dengan CCC, RCP, dan CR yang juga meningkat. Sedangkan, ICP dan PDP mengalami kenaikan dan penurunan setiap tahunnya pada periode 2011-2014. Selain melalui fenomena gap yang terjadi, penelitian terdahulu menunjukkan adanya perbedaan hasil (research gap) antara variabel CCC, RCP, ICP, PDP, dan CR. Variabel CCC menurut penelitian Amarjit Gill, dkk (2010) menyatakan bahwa CCC berpengaruh positif terhadap profitabilitas, sedangkan Mathuva (2010), Pouraghajan dan Milad (2012), Mogaka dan Jagongo (2013), Iqbal, dkk (2014), Enqvist, dkk (2014), dan Jamil, dkk (2015) menyatakan bahwa CCC berpengaruh negatif terhadap profitabilitas. Variabel RCP menurut penelitian Amarjit Gill, dkk (2010), Mathuva (2010), dan Iqbal, dkk (2014) berpengaruh negatif terhadap profitabilitas, sedangkan menurut penelitian Enqvist, dkk (2014) menyatakan bahwa RCP tidak berpengaruh terhadap profitabilitas. Variabel ICP menurut penelitian Mathuva (2010) dan Mogaka dan Jagongo (2013) berpengaruh positif terhadap profitabilitas, sedangkan menurut penelitian Iqbal, dkk (2014) dan Enqvist, dkk (2014) menyatakan ICP berpengaruh negatif terhadap profitabilitas. Variabel PDP menurut penelitian Mathuva (2010), Mogaka dan Jagongo (2013) ,dan Firdausiah (2015) berpengaruh positif terhadap profitabilitas, sedangkan menurut penelitian Iqbal, dkk (2014) dan Enqvist, dkk (2014) menyatakan bahwa PDP berpengaruh negatif terhadap profitabilitas. Variabel current ratio menurut penelitian Pouraghajan dan Milad (2012) dan Enqvist, dkk (2014) berpengaruh positif terhadap profitabilitas, sedangkan menurut penelitian Iqbal, dkk (2014) dan Jamil, dkk (2015) menyatakan 
bahwa current ratio berpengaruh negatif terhadap profitabilitas.

\section{KERANGKA PEMIKIRAN TEORITIS DAN PERUMUSAN HIPOTESIS}

Profitabilitas merupakan total hasil bersih dari seluruh rangkain keputusan dan kebijakan yang dilakukan oleh perusahaan (Brigham dan Weston, 1994). Profitabilitas merupakan salah satu aspek yang difokuskan sebagai tujuan oleh setiap perusahaan. Perusahaan yang memiliki tingkat pertumbuhan profitabilitas tinggi maka dapat diartikan bahwa pihak manajemen perusahaan memiliki kinerja yang baik dan telah mampu mengelola sumber daya yang dimiliki secara efektif dan efisien. Rasio profitabilitas adalah rasio yang menghubungkan antara laba dengan penjualan dan investasi dalam perusahaan (Van Horne dan Wachowicz, 2009).

Net profit margin (NPM) merupakan rasio yang digunakan untuk mengukur laba yang dihasilkan dari setiap rupiah penjualan atau keuntungan penjualan setelah menghitung keseluruhan biaya dan pajak penghasilan yang diperoleh (Martono, 2005). Secara sistematis, perhitungan NPM dilakukan dengan membagi laba bersih setelah pajak dengan penjualan (Brigham dan Weston, 1994).

\section{Pengaruh Siklus Konversi Kas terhadap Profitabilitas}

Cash conversion cycle (CCC) atau siklus konversi kas adalah rentang waktu antara pembelian bahan mentah dan pengumpulan kas atas penjualan produk jadi, terhitung setelah utang usaha terlunasi (Jamil dkk, 2015). Semakin pendek atau singkat siklus konversi kas, maka dapat dikatakan kinerja perusahaan baik sebab kas yang terikat dalam modal kerja dikelola secara efektif dan efisien sehingga laba yang akan diperoleh perusahaan semakin besar karena jangka waktu untuk kas berubah menjadi kas kembali singkat.

Hipotesis 1: Siklus konversi kas berpengaruh negatif terhadap profitabilitas.

\section{Pengaruh Periode Konversi Piutang Usaha terhadap Profitabilitas}

Receivable conversion period (RCP) atau periode konversi piutang usaha merupakan rentang waktu yang diperlukan dalam mengubah piutang usaha menjadi kas setelah terjadi penjualan scara kredit
(Firdausiah, 2015). Jangka waktu untuk mengkonversi piutang usaha yang pendek atau singkat dapat mengindikasikan pengelolaan komponen modal kerja yang berbentuk piutang usaha telah berjalan secara efektif dan efisien sehingga dapat dikatakan perusahaan memiliki kinerja yang baik dan dapat berkontribusi terhadap peningkatan profitabilitas perusahaan

Hipotesis 2: Periode konversi piutang usaha berpengaruh negatif terhadap profitabilitas.

\section{Pengaruh Periode Konversi Persediaan terhadap Profitabilitas}

Inventory conversion period (ICP) atau periode konversi persediaan adalah rentang waktu yang diperlukan dalam mengubah bahan mentah menjadi produk jadi dan setelah itu menjual produk tersebut (Firdausiah, 2015). Periode konversi persediaan yang berjalan dengan cepat atau singkat dapat menunjukkan kinerja perusahaan yang baik sehingga peningkatan profitabilitas pun terjadi

Hipotesis 3: Periode konversi persediaan berpengaruh negatif terhadap profitabilitas.

\section{Pengaruh Periode Penangguhan Utang}

\section{Usaha terhadap Profitabilitas}

Payable deferral period (PDP) atau periode penangguhan utang usaha adalah rentang waktu yang digunakan untuk perusahaan untuk melakukan pelunasan transaksi pembelian bahan mentah dan pembayaran gaji atau upah pegawai secara kredit (Firdausiah, 2015). Perusahaan yang memiliki rentang waktu pelunasan utang usaha yang tinggi atau lama maka dapat diindikasikan profitabilitas yang dimiliki perusahaan rendah sebab perusahaan tersebut memerlukan waktu yang lama untuk melunasi utang usahanya. Apabila profitabilitas suatu perusahaan menurun dapat dikatakan bahwa kinerja perusahaan tersebut buruk.

\section{Hipotesis 4: Periode penangguhan utang usaha berpengaruh negatif terhadap profitabilitas.}

\section{Pengaruh Current Ratio terhadap Profitabilitas}

Current ratio merupakan rasio yang didapat melalui perbandingan antara aktiva lancar dengan utang lancar (Brigham dan Weston, 1994). Apabila perusahaan memiliki CR yang tinggi hal ini mengindikasikan 
bahwa perusahaan tersebut memiliki aktiva lancar yang berlebih untuk membiayai utang lancarnya, sehingga dapat dikatakan juga bahwa perusahaan tersebut memiliki modal kerja yang cukup tinggi dan berdampak positif pada profitabilitas perusahaan. Positif di sini dimaksudkan dengan apabila CR suatu perusahaan meningkat, diikuti juga dengan profitabilitas yang meningkat dan juga sebaliknya.

Hipotesis 5: Current ratio berpengaruh positif terhadap profitabilitas.

\section{Kerangka Pemikiran Teoritis}

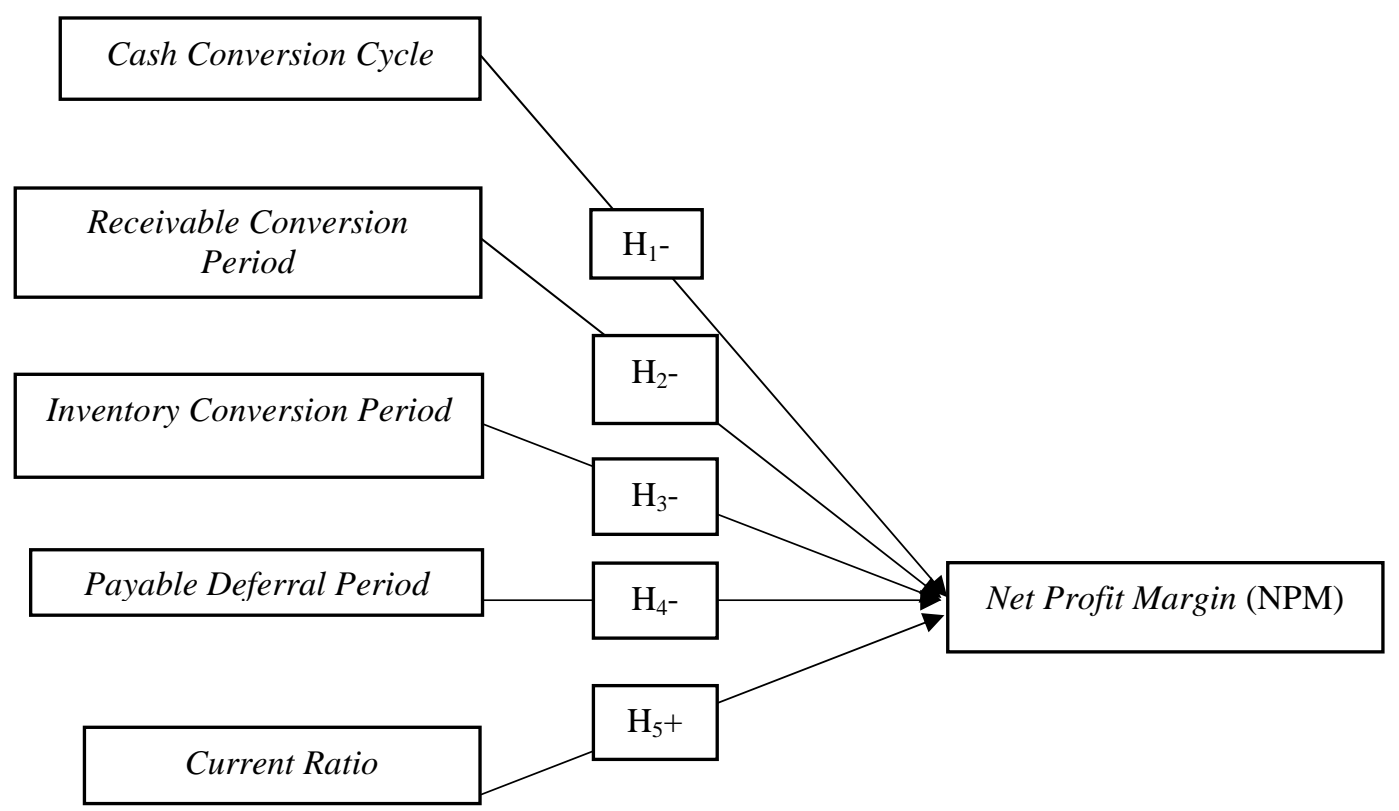

Sumber: Gamlath dan Rathiranee (2010), Amarjit Gill, dkk (2010), David M. Mathuva (2010), Pouraghajan dan Milad (2012), Ebenezer dan Asiedu (2013), Mogaka dan Jagongo (2013), Iqbal, dkk (2014), Enqvist, dkk (2014), Firdausiah (2015), dan Jamil, dkk (2015).

\section{METODE PENELITIAN}

Dalam penelitian ini digunakan delapan variabel yang terdiri dari satu variabel dependen dan lima variabel independen. Profitabilitas perusahaan yang diukur dengan rasio net profit margin (NPM) digunakan sebagai variabel dependen. Lima variabel independen dalam penelitian ini adalah CCC $\left(\mathrm{X}_{1}\right)$, RCP $\left(\mathrm{X}_{2}\right)$, ICP $\left(\mathrm{X}_{3}\right)$, PDP $\left(\mathrm{X}_{4}\right)$, dan $\mathrm{CR} \quad\left(\mathrm{X}_{5}\right)$. Penelitian ini menggunakan data sekunder berupa data yang berupa laporan tahunan perusahaan dan data kuantitatif lainnya selama periode tahun 2011 sampai dengan tahun 2014. Data-data terkait laporan keuangan dan annual report yang digunakan diperoleh melalui situs www.idx.co.id dan www.icamel.id. Populasi yang digunakan dalam penelitian ini adalah perusahaan manufaktur sektor industri dasar dan kimia yang terdaftar di Bursa Efek Indonesia (BEI) periode 2011-2014. Metode pengambilan sample yang digunakan adalah purposive sampling yang merupakan metode pengambilan sample sesuai pertimbangan subjektif peneliti, meliputi syarat yang harus dipenuhi agar mendapat sample yang representative. Melalui purposive sampling dihasilkan 25 perusahaan sebagai sample.

Penelitian ini menggunakan analisis regresi linear berganda dengan metode ordinary least square (OLS) yang digunakan dalam memperkirakan suatu garis regresi dengan jalan meminimalkan jumlah kuadrat kesalahan setiap observasi terhadap garis tersebut (Ghozali, 2005). Secara sistematis persamaan analisis regresi linear berganda melalui metode OLS dapat ditulis sebagai berikut:

$\mathbf{Y}=\alpha+\beta \mathbf{1} \mathbf{X}_{1}+\beta \mathbf{2} \mathbf{X}_{2}+\beta 3 \mathbf{X}_{3}+\beta \mathbf{4} \mathbf{X}_{4}+$

$$
\beta 5 \mathrm{X}_{5}+\mathrm{e}
$$

Keterangan :

$$
\begin{aligned}
& \text { a }=\text { Konstanta. } \\
& \mathrm{b} 1-\mathrm{b} 5=\text { Koefisien regresi. } \\
& \varepsilon=\text { Standard error. }
\end{aligned}
$$


Setelah melakukan analisis regresi linier berganda, maka dilakukan pengujian hipotesis. Uji hipotesis berfungsi untuk mengukur ketepatan fungsi regresi sampel dalam menaksir nilai aktual secara statistik melalui nilai koefisien determinasi, nilai statistik F, dan nilai statistik t (Ghozali, 2005).

\section{HASIL PENELITIAN DAN PEMBAHASAN}

Langkah awal yang dilakukan dalam analisis data adalah menentukan statistik deskriptif dari data penelitian. Tabel 1 menunjukkan statistik deskriptif yang meliputi nilai terendah, nilai tertinggi, nilai rata-rata, dan standar deviasi atau tingkat sebaran data.

Tabel 1

Statistik Deskriptif Variabel Penelitian

\begin{tabular}{lrrrrr}
\hline \multicolumn{7}{c}{ Descriptive Statistics } \\
\hline NPM & N & Minimum & Maximum & Mean & Std. Deviation \\
CCC & 100 & .06 & 55.54 & 9.0743 & 9.10886 \\
RCP & 100 & 7.28 & 378.91 & 89.3441 & 60.15961 \\
ICP & 100 & 15.85 & 128.88 & 57.6270 & 23.77632 \\
PDP & 100 & 1.06 & 266.90 & 70.9949 & 45.27357 \\
CR & 100 & .00 & 106.37 & 39.2779 & 25.29428 \\
\hline Valid N (listwise) & 100 & .22 & 9.34 & 2.4213 & 1.74740 \\
\hline Sumber: Data sekunder diolah, 2016 & 100 & \multicolumn{7}{l}{} \\
\end{tabular}

Berdasarkan statistik deskriptif di atas dapat dilihat bahwa data penelitian $(\mathrm{N})$ yang digunakan berjumlah 100 yang diperoleh dari 25 perusahaan sampel dikalikan dengan periode tahun penelitian (4 tahun). Deskripsi mengenai profitabilitas dalam penelitian ini ditunjukkan melalui net profit margin (NPM) selama periode 2011-2014 memiliki nilai rata-rata (mean) sebesar 9,074\%. Hal ini menunjukkan secara rata-rata perusahaan sample mendapatkan laba bersih hingga $9,074 \%$ dari modal sendiri yang dimiliki perusahaan. Nilai terendah NPM sebesar $0,06 \%$ pada PT. Alumindo Light Metal Industry Tbk tahun 2014 dan nilai tertinggi sebesar 55,54\% pada PT. Hanson International Tbk tahun 2011. Tingkat sebaran data (standar deviasi) menunjukkan adanya penyimpangan sebesar $9,108 \%$ terhadap variabel profitabilitas.

Deskripsi mengenai manajemen modal kerja dalam penelitian ini yang pertama ditunjukkan melalui siklus konversi kas atau cash conversion cycle (CCC) yang menunjukkan nilai rata-rata (mean) sebesar 89,34 hari. Hal ini menunjukkan bahwa perusahaan sampel secara rata-rata mengalami siklus konversi kas selama 89,34 hari. Siklus konversi kas tersingkat terjadi selama 7,28 hari pada PT Holcim Indonesia Tbk tahun 2013 dan siklus konversi kas terlama terjadi selama 378,91 hari pada PT. Hanson International Tbk tahun 2012.

Deskripsi mengenai manajemen modal kerja dalam penelitian ini yang kedua ditunjukkan melalui periode konversi piutang usaha atau receivable conversion period (RCP) dengan nilai rata-rata (mean) sebesar 57,63 hari. Hal ini menunjukkan bahwa periode konversi piutang usaha rata-rata pada perusahaan sampel terjadi selama 57,63 hari. Periode konversi piutang usaha tersingkat terjadi selama 15,85 hari pada PT. Japfa Comfeed Indonesia Tbk tahun 2011 dan paling lama terjadi 128,88 hari pada PT. Hanson International Tbk tahun 2014.

Deskripsi mengenai manajemen modal kerja dalam penelitian ini yang ketiga ditunjukkan melalui periode konversi persediaan atau inventory conversion period (ICP) dengan nilai rata-rata (mean) sebesar 70,99 hari. Hal ini menunjukkan bahwa periode konversi persediaan rata-rata terjadi pada perusahaan sampel selama 70,99 hari. Periode konversi persediaan paling singkat terjadi selama 1,06 hari pada PT. Hanson 
International Tbk tahun 2014 dan terlama terjadi selama 266,90 hari pada PT. Hanson International Tbk kembali tetapi pada tahun yang berbeda yaitu 2012 .

Deskripsi mengenai manajemen modal kerja dalam penelitian ini yang keempat ditunjukkan melalui periode penangguhan utang usaha atau payable deferral period (PDP) dengan nilai rata-rata (mean) sebesar 39,27 hari. Hal ini menunjukkan bahwa periode penangguhan utang usaha rata-rata pada perusahaan sampel terjadi selama 39,27 hari. Periode penangguhan utang usaha terjadi paling cepat selama 0 hari pada PT. Hanson International Tbk tahun 2014 yang berarti utang usaha dapat terlunasi pada hari yang sama dan paling lama terjadi selama 106,37 hari pada PT Alkindo Naratama Tbk tahun 2013.

Deskripsi mengenai manajemen modal kerja dalam penelitian ini yang kelima ditunjukkan melalui current ratio (CR) dengan nilai rata-rata (mean) sebesar 2,421. Hal ini menunjukkan bahwa tingkat kemampuan perusahaan sampel membayar utang lancar dengan aset lancar yang dimiliki rata-rata sebesar 2,421. Presentase CR terendah selama ini sebesar 0,222 pada PT. Hanson International tahun 2011 dan tertinggi yang dicapai sebesar 9,345 pada PT. Lion Metal Works Tbk tahun 2012. Standar deviasi menunjukkan terdapat penyimpangan sebesar 1,747 terhadap CR.

\section{Pembahasan Hasil Penelitian}

Tahap awal yang harus dilakukan sebelum melakukan analisis regresi berganda adalah uji asumsi klasik. Penelitian ini telah terbebas dari penyimpangan asumsi klasik yang ditandai dengan data terdistribusi secara normal, tidak terjadi multikolinearitas, tidak terjadi heterokedastisitas, dan tidak ada autokorelasi. Data terdistribusi secara normal sebab grafik histogram memberikan pola distribusi simetris dengan tidak menceng ke kiri atau kanan (simetris), grafik normal pplot dapat dinyatakan bahwa data terdistribusi secara normal karna terlihat titiktitik menyebar disekitar garis diagonal dan penyebarannya tidak terlalu menjauhi garis diagonal, dan hasil Kolmogorov-Smirnov > 0,05 yaitu sebesar 0,321 . Uji selanjutnya, uji autokorelasi dilakukan melalui uji statistik run test, memperlihatkan nilai probabilitas 0,375 dengan taraf signifikan pada 0,05 maka dapat disimpulkan bahwa residual random atau bebas autokorelasi. Selain itu, uji multikoleniatiras dari seluruh variabel menunjukan nilai VIF $<10$ dan tolerance $>0,10$ dapat dinyatakan bahwa tidak terjadi multikolinearitas dalam penelitian ini. Uji asumsi klasik yang terakhir yaitu uji heterokedastisitas dilakukan melalui grafik scatterplot menunjukkan tidak terdapat pola yang jelas, titik-titik menyebar di atas dan di bawah angka 0 pada sumbu $\mathrm{Y}$ dan uji statistik Spearman Rho dapat dilihat bahwa signifikansi dari seluruh variabel bebas yang digunakan dalam penelitian melebihi 0,05 sehingga dapat disimpulkan bahwa model regresi homoskedastisitas atau terbebas dari gejala heteroskedastisitas.

Setelah data penelitian sudah memenuhi seluruh asumsi klasik, maka selanjutnya dapat dilakukan analisis regresi dan pengujian hipotesis. Uji hipotesis dilakukan dengan uji koefisien determinasi $\left(\mathrm{R}^{2}\right)$, uji statistik $\mathrm{F}$, dan uji statistik t. Berdasarkan hasil uji koefisien determinasi yang ditinjau melalui nilai adjusted $R^{2}$ dihasilkan sebesar 0,454. Hasil uji statistik F dapat diketahui bahwa nilai $\mathrm{F}$ pada model regresi sebesar 11,302 dengan tingkat signifikansi sebesar 0,000. Nilai signifikansi tersebut membuktikan bahwa model dalam penelitian ini layak untuk diteliti karena memenuhi Goodnes of Fit. Berikut merupakan hasil analisis regresi dengan menggunakan metode analisis regresi linier berganda dan pengujian hipotesis disajikan pada tabel 2 sebagai berikut: 
Tabel 2

Hasil Uji Statistik t

Coefficients $^{\mathrm{a}}$

\begin{tabular}{|c|c|c|c|c|c|c|}
\hline \multirow{2}{*}{\multicolumn{2}{|c|}{ Model }} & \multicolumn{2}{|c|}{$\begin{array}{c}\text { Unstandardized } \\
\text { Coefficients }\end{array}$} & \multirow{2}{*}{$\begin{array}{c}\begin{array}{c}\text { Standardized } \\
\text { Coefficients }\end{array} \\
\text { Beta }\end{array}$} & \multirow[b]{2}{*}{$\mathbf{t}$} & \multirow[b]{2}{*}{ Sig. } \\
\hline & & B & Std. Error & & & \\
\hline \multirow[t]{6}{*}{1} & (Constant) & 1.525 & 3.505 & & .435 & .665 \\
\hline & Ln.CCCt & -2.169 & 1.040 & -.306 & -2.086 & .041 \\
\hline & Abs.RCPt & .038 & .042 & .108 & .902 & .371 \\
\hline & Abs.ICPt & .011 & .030 & .053 & .366 & .716 \\
\hline & Ln.PDPt & 1.818 & .625 & .351 & 2.909 & .005 \\
\hline & CRt & 3.010 & .479 & .693 & 6.283 & .000 \\
\hline
\end{tabular}

a. Dependent Variable: NPMt

Sumber: Data sekunder diolah, 2016
Rumus persamaan regresi linier berganda yang dihasilkan dari hasil uji statistik t pada Tabel 2 sebagai berikut:

$$
\begin{aligned}
\mathrm{NPM} & =1,525+(-2,169) \mathrm{CCC}+(0,038) \\
& \mathrm{RCP}+0,011 \mathrm{ICP}+(1,818) \mathrm{PDP}+ \\
& 3,010 \mathrm{CR}
\end{aligned}
$$

Berdasarkan hasil uji statistik t pada Tabel 4.12 dalam penelitian ini hanya terdapat tiga variabel independen yang memiliki signifikansi dibawah $0,05(\alpha)$ atau dengan kata lain variabel tersebut memiliki pengaruh yang signifikan terhadap variabel dependen (NPM) yaitu CCC, PDP, dan CR. Sebaliknya RCP dan ICP menunjukkan tingkat signifikansi melebihi $0,05(\alpha)$ yang berarti tidak berpengaruh signifikan terhadap variabel dependen (NPM).

Hasil pengujian hipotesis pertama menghasilkan siklus konversi kas atau cash conversion cycle (CCC) berpengaruh secara negatif dan signifikan terhadap profitabilitas (NPM). Siklus konversi kas yang berjalan dengan singkat dapat menunjukkan pengelolaan modal kerja dalam perusahaan berjalan secara efektif dan efisien sehingga mengindikasikan kinerja perusahaan tersebut bagus, sebab turut ditunjukkan dengan peningkatan profitabilitas. Hasil atas hipotesis ini konsisten terhadap penelitian yang telah dilakukan oleh Mathuva (2010), Mogaka dan Jagongo (2013), Iqbal, dkk (2014), Enqvist, dkk (2014), dan Jamil, dkk (2015).
Hasil pengujian hipotesis kedua menghasilkan periode konversi piutang usaha atau receivable conversion period ( $\mathrm{RCP})$ memiliki pengaruh positif dan tidak signifikan terhadap profitabilitas (NPM). Hal ini menunjukkan bahwa terjadinya peningkatan maupun penurunan pada periode konversi piutang usaha tidak mempengaruhi profitabilitas secara signifikan. Hasil penelitian ini konsisten terhadap hasil dari penelitian yang dilakukan oleh Mogaka dan Jagongo (2013), Enqvist (2014) dan Firdausiah (2015).

Hasil pengujian hipotesis ketiga menghasilkan periode konversi persediaan atau inventory conversion period (ICP) memilki pengaruh positif dan tidak signifikan terhadap profitabilitas (NPM). Hal ini dapat diartikan bahwa semakin lama atau tinggi periode konversi persediaan (ICP), maka tidak akan mempengaruhi tingkat profitabilitas secara signifikan dan juga sebaliknya. Hasil penelitian ini juga konsisten terhadap hasil penelitian yang dilakukan oleh Amarjit Gill, dkk (2010) dan Ebenezer dan Asiedu (2013).

Hasil pengujian hipotesis keempat menghasilkan bahwa periode penangguhan utang usaha atau payable deferral period (PDP) berpengaruh positif dan signifikan terhadap profitabilitas (NPM). Hal ini mengindikasikan bahwa semakin singkat atau rendah periode penangguhan utang usaha memberikan dampak atau pengaruh terhadap 
penurunan profitabilitas dan juga sebaliknya. Hasil penelitian ini konsisten terhadap hasil dari penelitian yang dilakukan oleh Mathuva (2010) dan Mogaka dan Jagongo (2013).

Hasil pengujian hipotesis kelima menghasilkan bahwa current ratio (CR) berpengaruh secara positif dan signifikan terhadap profitabilitas (NPM). Hal ini mengindikasikan bahwa CR yang tinggi akan berpengaruh terhadap peningkatan profitabilitas dan begitu juga sebaliknya. Hasil uji hipotesis 5 konsisten terhadap hasil penelitian yang telah dilakukan oleh Pouraghajan dan Milad (2012) dan Enqvist, dkk (2014).

\section{KESIMPULAN}

Berdasarkan hasil penelitian ini menunjukan beberapa faktor yang dapat mempengaruhi profitabilitas perusahaan. Dari lima faktor yang diteliti sebagai variabel independen (siklus konversi kas (CCC), periode konversi piutang usaha (RCP), periode konversi persediaan (ICP), periode penangguhan utang usaha (PDP), dan current ratio (CR)), terbukti bahwa tiga variabel yang dinyatakan memiliki pengaruh yang signifikan yaitu CCC, PDP, dan CR.

Keterbatasan penelitian ini ditunjukkan melalui nilai adjusted $R^{Z}$ pada koefisien determinasi yang menghasilkan sebesar 0,454 dan berarti hanya $45,4 \%$ variabilitas variabel independen dapat menjelaskan variabilitas variabel dependen, 54,6\% dijelaskan melalui faktor-faktor lain yang tidak digunakkan dalam penelitian.

Ada pun saran dari pnelitian ini dapat berguna bagi beberapa pihak. Pertama, pihak manajemen perusahaan, hasil dan kesimpulan penelitian ini dapat dijadikan sebagai pertimbangan bagi pihak manajemen perusahaan dalam mengelola modal kerja yang dapat berpengaruh terhadap kinerja perusahaan yang ditunjukkan melalui profitabilitas. Profitabilitas yang semakin meningkat dapat ditunjang melalui, current ratio (CR) yang tinggi sebab menujukkan aktiva lancar suatu perusahaan mampu melunasi utang lancarnya sehingga perusahaan terhindar dari risiko terkena likuidasi, periode penangguhan utang usaha (PDP) yang lama sehingga menghindari perusahaan terkena risiko likuidasi, dan siklus konversi kas (CCC) yang semakin cepat sehingga menunjukkan kas yang telah berubah menjadi produk dan piutang berubah menjadi kas kembali dengan cepat. Faktorfaktor yang mempengaruhi profitabilitas tersebut dapat mendorong manajemen perusahaan untuk lebih efektif dan efisien dalam mengelola modal kerja, sebab hal itu dapat meunjukkan apakah kinerja suatu perusahaan berjalan secara optimal dan dapat mempengaruhi tingkat profitabilitas.

Kedua, bagi akademisi atau peneliti selanjutnya, hasil dan kesimpulan penelitian ini dapat dijadikan sebagai pengetahuan tambahan bagi pihak akademisi tentang pengaruh modal kerja terhadap profitabilitas perusahaan terutama pada variabel-variabel terkait yang digunakan dalam penelitian. Hal ini dapat menunjang diadakan penelitian selanjutnya tentang tema yang serupa dengan variabel-variabel yang berbeda sebab telah diketahui nilai adjusted $R^{2}$ hanya menghasilkan sebesar 0,454 atau 45,4\%, maka terdapat $54,6 \%$ faktor-faktor lain yang tidak digunakkan dalam penelitian sebagai variabel.

\section{REFERENSI}

Anindityo. 2013, Juli 18. Media Manufaktur Indonesia: Manufaktur Indonesia Terkuat di ASEAN. http://www.mmindustri.co.id/manufaktur-indonesia-terkuat-di-asean/

Ardhy. 2015, Februari 2. Sindonews: Industri Manufaktur RI 2014 Tumbuh 4,47\%. http://ekbis.sindonews.com/read/959040/34/industri-manufaktur-ri-2014-tumbuh-4-471422872880

Brigham, E.F., and Weston, J.F. 1994. Essentials of Managerial Finance. Edisi Kesembilan. Jakarta: Erlangga.

Brigham, Eugene F. dan Joel E. Houston. 2011. Dasar-Dasar Manajemen Keuangan : Essentials Of Financial Management. Buku 2. Edisi 11. Salemba Empat. Jakarta.

Bri. 2014, Oktober 15. Britama.com: Didongkrak Sektor Industri Dasar dan Kimia, IHSG Melonjak. http://www.britama.com/index.php/2015/10/didongkrak-sektor-industri-dasarkimia-dan-keuangan-ihsg-melonjak-323-persen 
Ebenezer, A.B. dan M.K. Asiedu. 2013. The Relationship Between Working Capital Management and Profitability of Listed Manufacturing Companies in Ghana. International Journal of Business and Social Research, Vol. 3, No. 2, Februari 2013.

Enqvist, J.; M. Graham; dan Jussi N. 2014. The impact of working capital management on firm profitability in different business cycles: Evidence from Finland. Research in International Business and Finance, Vol. 32, 2014, pp. 36-49.

Firdausiah, A. 2015. Pengaruh Manajemen Modal Kerja Terhadap Profitabilitas (Studi pada Perusahaan Food and Beverages yang Listing di BEI periode 2009-2013). Jurnal. Malang; Universitas Brawijaya.

Ghozali, I. 2005. Aplikasi Analisis Multivariate dengan program SPSS. Badan Penerbit Universitas Diponegoro, Semarang.

Gamlath, G R M dan Rathiranee, Y. 2010. Effects of Working Capital Management and Profitability: Evidence From Listed Commercial Banks in Sri Lanka. Journal of Business Studies. Faculty of management Studies \& Commerce, University of Jaffna, Sri Lanka. ISSN: $2362-026$.

Gill, Amarjit; Nahum Biger; dan Neil Mathur. 2010. The Relationship Between Working Capital Management and Profitability: Evidence from The United States. Business and Economics Journal, Vol 2010: BEJ-10.

Hasselbein et.al, Frances. 2003. On High Performance Organization. Jakarta: Elexmedia Komputindo.

Iqbal, N.; Naveed Ahmad; dan Kanwal. 2014. Impact of Working Capital Management on Firm's Profitability: Evidences Textile Sector of Pakistan. Journal of Business and Management Review, Vol. 2, No. 5, 2014.

Jamil, S.A.; Mawih K.A.; dan Faris N. 2015. The Effect of Working Capital Management Efficiency on the Operating Performance of the Industrial Companies in Oman. International Journal of Economics and Financial Issues, Vol. 5, No. 4, pp. 897-904.

Kuncoro, Mudrajad. 2005. Metode Kuantitatif Teori dan Aplikasi Untuk Bisnis dan Ekonomi. Edisi Kedua. Yogyakarta: Unit Penerbit dan Percetakan AMP YKPN.

Kom. 2015, Januari 29. Kompas: Invetasi Manufaktur Naik. http://print.kompas.com/baca/KOMPAS_ART0000000000000000011688037

Mangkunegara, Anwar Prabu. 2005. Evaluasi Kinerja. Bandung: Refika Aditama.

Mathuva, David. 2010. The Influence of Working Capital Management Components on Corporate Profitability: A Survey on Kenyan Listed Firms. Research Journal of Business Management, Vol. 4, No. 1, pp 1-11.

Martono dan Agus Harjito. 2005. Manajemen Keuangan. Yogyakarta: Ekonisia.

Munawir, S. 1980. Analisis Laporan Keuangan. Edisi Keempat. Penerbit Liberty. Yogyakarta.

Mogaka, Daniel dan Ambrose Jagongo. 2013. Working Capital Management and Firm Profitability: Empirical Evidence from Manufacturing and Construction Firms Listed on Nairobi Securities Exchange, Kenya. International Journal of Accounting and Taxation, Vol. 1, No. 1.

Nasreen, S.; Farida K.; dan S.S. Pirzada. 2014. Impact of Working Capital Management on Firm'S Profitability. Research Journal of Finance and Accounting, Vol. 5, No. 11, ISSN 22221697 (Paper) ISSN 2222-2847 (Online).

Pouraghajan, A. dan Milad E. 2012. Impact of Working Capital Management on Profitability and Market Evaluation: Evidence from Tehran Stock Exchange. International Journal of Business and Social Science, Vol. 3, No. 10, Special Issue - May 2012.

Quayyum, Sayeda T. 2011. Effects of Working Capital Management and Liquidity: Evidence from the Cement Industry of Bangladesh. Journal of Business and Technology, Vol. 6, No. 1, Januari-Juni 2011.

Riyanto, B. 2013. Dasar-Dasar Pembelanjaan Perusahaan. Yogyakarta: Yayasan Badan Penerbit Universitas Gadjah Mada.

Sawir, Agnes. 2005. Analisis Kinerja Keuangan dan Perencanaan Keuangan Perusahaan. Penerbit BPFE. Yogyakarta.

Subramanyam , K.R., dan John Wild. 2010. Financial Statement Analysis. Edisi Kesepuluh. Jakarta: Penerbit Salemba Empat. 
Indradewi and Widyawarti ./Jurnal Studi Manajemen \& Organisasi 13 (2016) Desember 121 - 130 http://ejournal.undip.ac.id/index.php/smo

Van Horne, J.C., and Wachowicz Jr, J.M. 2009. Fundamentals of Financial Management. 13thed,.New Jersey: Prent ice Hall Inc.

Weston, J, Fred and Thomas E. Copeland. 1999. Manajemen Keuangan. Edisi Kesembilan. Jilid Satu dan Dua. Binarupa Aksara. Jakarta.

Walsh, Ciaran. 2004. Key Management Ratios. Edisi Ketiga. Jakarta: Penerbit Erlangga. 